\title{
Physicochemical quality characteristics of hot water extracts of processed ginseng based on different heat treatments
}

\author{
Yoon-Han Kang ${ }^{1,2 *}$, Rui Zhou ${ }^{2}$, Hyo Jin Kim ${ }^{1}$, Ji Eun Kim³ ${ }^{3}$, Il Shik Shin ${ }^{3}$ \\ ${ }^{1}$ Department of Food Processing and Distribution, Gangneung-Wonju National University, Gangneung 25457, Korea \\ ${ }^{2}$ Department of Food Science, Gangneung-Wonju National University, Gangneung 25457, Korea \\ ${ }^{3}$ Department of Marine Food Science and Technology, Gangneung-Wonju National University, Gangneung 25457, Korea
}

\section{열처리 방법에 따른 가공 인삼 열수추출물의 이화학적 품질 특성}

\author{
강윤한 ${ }^{1,2 *} \cdot$ 저우뤠이 ${ }^{2} \cdot$ 김효진 $^{1} \cdot$ 김지은 $^{3} \cdot$ 신일식 $^{3}$ \\ ${ }^{1}$ 강릉원주대학교 식품가공유통학과, ${ }^{2}$ 강릉원주대학교 식품과학과, ${ }^{3}$ 강릉원주대학교 해양식품공학과
}

\begin{abstract}
The present study was caried out to investigate the physicochemical properties of hot water extracts of red ginseng powder prepared by two-stage hot air drying method using steamed ginseng and steaming liquid for $2.5 \mathrm{~h}$ under high-temperature and high-pressure autoclave condition. The total polyphenols, total flavonoids, total sugar, acid polysaccharides and crude saponin in hot water extracts from red ginseng powder were analyzed and determined, and the flavor components of ginseng were measured using color difference meter and an electronic tongue. The total polyphenol, total flavonoid, total polysaccharide, and acid polysaccharide of the red ginseng hot water extract obtained by autoclaving (ARG) were $9.06 \mathrm{mg}$ GAE/g, $3.38 \mathrm{mg} \mathrm{NE} / \mathrm{g}, 35.22 \mathrm{~g} / 100 \mathrm{~g}$, and $10.90 \mathrm{~g} / 100 \mathrm{~g}$, respectively. The final contents of the total polyphenols, total flavonoids, crude saponin were higher than those determined using other red ginseng methods; the time required for steamed red ginseng production reduced. The total ginsenoside content of ginseng including Rb1 was $10.69 \mathrm{mg} / \mathrm{g}$, which is the lowest ARG. The processing conditions affected the conversion to ginsenosides unique to red ginseng. Red ginseng and steaming liquid obtained from the autoclave are expected to be in need for non-food materials and products as well as foods by improving the flavor components through conversion of red ginseng components into low molecular weight.
\end{abstract}

Key words : red ginseng, extracts, total polyphenol, saponins, ginsenosides

\section{서 론}

수삼으로부터 홍삼을 제조하면 홍삼에만 존재하는 prosapogenin(ginsenoside $\mathrm{Rg} 3, \mathrm{Rg} 5$ 및 Rk1)이 제조 가능하 고 홍삼추출물의 추출조건에 따라 ginsenoside의 조성에 큰 차이가 있는 것으로 나타났으며, $100^{\circ} \mathrm{C}, 24$ 시간 추출하였을 때 함량이 최대인 것으로 보고되었다(1). 최근에는 홍삼추

*Corresponding author. E-mail : yhkang@gwnu.ac.kr Phone : 82-33-640-2966, Fax : 82-33-640-2966

Received 15 December 2017; Revised 5 February 2018; Accepted 18 February 2018.

Copyright (c) The Korean Society of Food Preservation. All rights reserved.
출시 $100^{\circ} \mathrm{C}, 2$ 시간 추출에 비해, 초음파 $\left(100^{\circ} \mathrm{C}\right) 1-15$ 시간 특히 $100^{\circ} \mathrm{C}, 12$ 시간 초음파 가공 추출할 때 고함량의 $\mathrm{Rg} 3$, $\mathrm{Rg} 5, \mathrm{Rk} 1$ 이 함유된 것으로 보고되었다. 또한 인삼의 추출조 건 중 가온을 적용한 가온 초음파 추출법으로 ginsenoside 함량이 건강기능식품의 기준 및 규격의 방법보다 떨어지지 않음이 보고되었다(2). 홍삼 제조시 고온으로 증숙하는 과 정을 통하여 인삼의 주요 진세노사이드 중 특이 비극성 진세노사이드인 $\mathrm{Rg} 3, \operatorname{Rg} 5$ 등으로의 전환이 촉진된다(3). 홍삼 흑삼 분말을 이용한 양갱 제조에서 ginsenoside 중 $\mathrm{Rb} 1, \mathrm{Rb} 2$ 및 $\mathrm{Rc}$ 는 홍삼에서, $\mathrm{Rg} 3$ 와 compound $\mathrm{K}$ 의 함량은 흑삼에서 높게 나타났다(4). 구증구포의 방법으로 제조한 홍삼류의 외형이 검은색을 띠고 있는 흑삼(black ginseng)이 제품으로 개발되고 있으며, 흑삼의 경우 사포닌 중 
prosapogenin류의 함량이 높다고 하였다(5). 홍삼 엑스(25 $\left.{ }^{\circ} \mathrm{Brix}\right)$ 를 autoclave로 $120^{\circ} \mathrm{C}$ 의 고온 처리시 사포닌 변환에 의해 ginsenoside $\mathrm{Rg} 3$ 의 함량이 약 2 배 증가하였으나 다른 유효한 사포닌을 포함하여 총사포닌의 $65 \%$ 정도가 소실되 는 결과를 나타내었다(6). 홍삼추출액 제조시 온도가 높을 수록 시간이 경과할수록 갈변반응이 촉진되었으며, 맛을 증진하고 특수한 진세노사이드의 함량을 높이기 위해서는 추출온도와 추출시간을 더욱 세분화해야 한다고 하였다 (7). 또한 홍삼의 수용성 갈변물질은 항산화 활성이 있다고 보고하였으며(8) 홍삼추출물을 첨가한 소시지의 품질 특성 (9) 등이 보고되었다.

인삼의 파이토케미칼 성분을 강화하기 위한 신가공기술 개발은 가공방법에 의해 진세노사이드가 주를 이루고 있으 나 기타 활성 성분인 페놀성 화합물, 산성다당체 등 유용성 분에 대한 연구도 이루어져야 한다.

본 연구는 autoclave에 의한 홍삼제조법 등 열처리 방법 에 따른 전환 사포닌 함유 증삼액인 용출액과 이를 이용한 가공품인 홍삼으로부터 열수추출물을 제조하여 진세노사 이드 뿐만 아니라 총 폴리페놀, 총 플라보노이드, 조사포닌, 색도 등 이화학적 품질 특성을 조사하여 일반식품 뿐만 아니라 기능성 소재로서 활용도를 높이고자 한다.

\section{재료 및 방법}

\section{실험 재료}

홍삼을 제조하기 위한 수삼은 풍기인삼농협으로부터 2017년 7월에 구입한 6년근을 시료로 하였다. Table 1과 같이 뇌두, 주근, 지근, 세근의 평균 중량은 각각 $2.05 \mathrm{~g}$, $16.95 \mathrm{~g}, 3.27 \mathrm{~g}, 0.61 \mathrm{~g}$ 이며, 주근의 길이는 $91.2 \mathrm{~mm}$ 이었다.

Table 1. The basic characteristics of different part of 6-year old ginseng

\begin{tabular}{ccccc}
\hline Characteristics & Rhizome & Main root & Lateral root & Fine root \\
\hline Weight $(\mathrm{g})$ & $2.05 \pm 0.11^{1)}$ & $16.95 \pm 0.82$ & $3.27 \pm 0.14$ & $0.61 \pm 0.03$ \\
Lengh $(\mathrm{mm})$ & $21.6 \pm 0.98$ & $91.2 \pm 4.15$ & $74.7 \pm 3.23$ & $71.4 \pm 3.21$ \\
Diameter $(\mathrm{mm})$ & $11.1 \pm 0.37$ & $19.8 \pm 0.83$ & $4.1 \pm 0.18$ & $1.68 \pm 0.08$ \\
\hline
\end{tabular}

${ }^{1)}$ Values are mean $\pm \mathrm{SD}(\mathrm{n}=10)$.

\section{인삼의 가공}

수삼을 수돗물로 씻고 6 개의 시료군으로 나누었다. 시료 1 은 $3 \mathrm{~mm}$ 두께로 자른 후 $70^{\circ} \mathrm{C}$ 에서 25 시간 열풍건조하고

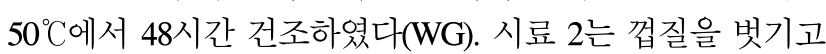
두 개의 부분으로 나눴다. 한 부분은 잔뿌리를 함유한 껍질 부분으로 이것을 $70^{\circ} \mathrm{C}$ 에서 24 시간 열풍 건조하였고, 그 다 음 $50^{\circ} \mathrm{C}$ 에서 48 시간 건조하였다(SWG). 시료 3 은 껍질이 없는 과육 부분이며 이것은 $3 \mathrm{~mm}$ 두께로 자른 후 $70^{\circ} \mathrm{C}$ 에서
24 시간 열풍 건조시키고, 이어서 건조기로 $50^{\circ} \mathrm{C}$ 에서 48 시 간 건조하였다(NSWG). 시료 4는 조리용 찜솥에서 스팀으 로 2 시간 30 분 동안 열처리하였다. 스팀된 샘플은 $3 \mathrm{~mm}$ 두께로 자른 후 $70^{\circ} \mathrm{C}$ 에서 24 시간 동안 열풍건조를 하였고, 그 다음 $50^{\circ} \mathrm{C}$ 에서 48 시간 동안 건조하였다(SRG). 시료 5 는 전기보온밥솥(CR-1713R, CUCKOO, Yangsan, Korea)에서 스팀으로 2 시간 30 분 동안 열처리하였다. 스팀된 샘플은 $3 \mathrm{~mm}$ 두께로 잘라 $70^{\circ} \mathrm{C}$ 에서 24 시간 열풍 건조시켰고, 그 다음 건조기로 $50^{\circ} \mathrm{C}$ 에서 48 시간 건조하였다(RCRG). 시료 6의 제조는 세척한 수삼을 autoclave(J-NAS4, JISICO, Seoul, Korea)로 증삼하기 위해 시험용 체(sieve No.18, Chung Gye Sang Gong Sa, Seoul, Korea) 2칸에 각각 수삼 4 뿌리씩 총 8 뿌리를 담고 아래에 증삼 유출액을 받기 위한 팬(pan)을 두었다. 고압솥의 운전 조건은 온도 $121^{\circ} \mathrm{C}$, 압력 $1.2 \mathrm{~kg}_{f} / \mathrm{cm}^{2}$, 작동시간 2.5 시간으로 하였다. 시간이 종료되 어 스팀압이 0 으로 되면 autoclave로부터 인삼과 스팀 증삼 액을 꺼내 상온에서 냉각하였다. 건조는 인삼을 건조 트레 이에 담아 건조기로 $70^{\circ} \mathrm{C}$ 에서 10 시간될 때 진공회전농축기 (SB-1100, Eyela, Tokyo, Japan)로 농축(18 ${ }^{\circ}$ Brix)하여 준비 한 스팀 증삼액을 브러쉬로 도포하여 $70^{\circ} \mathrm{C}$ 에서 8 시간 건조 하였다. 연속하여 $3 \mathrm{~mm}$ 의 두께로 자르고 $70^{\circ} \mathrm{C}$ 에서 12 시간 더 건조하였다. 이어서 $50^{\circ} \mathrm{C}$ 에서 $12-16$ 시간 건조하였다 (ARG). 건조한 인삼은 분쇄하여 $40 \mathrm{mesh}$ 체로 여과하여 분 말로 하였으며 추후 분석을 위해 폴리에틸렌 백에 담아 $-20^{\circ} \mathrm{C}$ 냉동고 안에 저장해 두고 사용하였다.

\section{열수추출물의 제조}

열수추출물의 제조는 가공 인삼 분말 $1 \mathrm{~g}$ 에 증류수 50 $\mathrm{mL}$ 를 가하고, 균질기(PH 91, SMT Co., Yokohama, Japan)로 $10,000 \mathrm{rpm}$ 에서 1 분간 균질화 시킨 후 $100 \mathrm{~mL}$ 메스플라스 크에 정용하였다. 열수추출은 수욕조에서 $95^{\circ} \mathrm{C}, 1$ 시간 동안 환류 추출하였다. 추출 종료 후 냉각하여 여과(Whatman No.2)하고 용기에 담아 추후 분석을 위해 $-70^{\circ} \mathrm{C}$ 에서 저장하 였다.

\section{총 폴리페놀 함량}

총 폴리페놀 함량은 추출물 $0.25 \mathrm{~mL}$ 에 Folin-Ciocalteu 시약 $0.25 \mathrm{~mL}$, 증류수 $2 \mathrm{~mL}$ 를 각각 첨가하여 실온에서 3 분 동안 정치한 후 $20 \% \mathrm{Na}_{2} \mathrm{CO}_{3} 0.25 \mathrm{~mL}$ 를 첨가하여 수조 에서 $37^{\circ} \mathrm{C}, 30$ 분간 반응 후 흡광도를 분광광도계(T60 U, Sunil Eyela Co., Seongnam, Korea)를 이용하여 $750 \mathrm{~nm}$ 에서 측정하였다. 이때 사용한 표준물질은 gallic acid(SigmaAldrich Co., St. Louis, MO, USA)의 검량곡선으로부터 함량 을 산출하였다.

\section{총 플라보노이드 함량}

총 플라보노이드 함량은 추출물 $0.2 \mathrm{~mL}$ 에 diethylene glycol $2 \mathrm{~mL}$ 를 첨가하여 잘 혼합한 후 $1 \mathrm{~N} \mathrm{NaOH} 0.2 \mathrm{~mL}$ 를 
가하여 수옥조에서 $37^{\circ} \mathrm{C}, 1$ 시간 반응시킨 후 $420 \mathrm{~nm}$ 에서 흡광도를 측정하였다. 함량 산출을 위한 플라보노이드 표 준물질은 naringin(Sigma-Aldrich)을 이용하였다.

\section{총당 함량}

총당 함량은 추출물 $0.5 \mathrm{~mL}$ 에 $5 \%$ 페놀 시약 $0.5 \mathrm{~mL}$ 첨가한 후 $95 \%$ 황산 $2.5 \mathrm{~mL}$ 를 첨가하여 잘 혼합한 후 실온 에서 5 분간 방치하였다. 수옥상에서 15 분간 가열하고 490 $\mathrm{nm}$ 에서 흡광도를 측정한다. 표준곡선을 이용한 함량 산출 은 fructose를 표준물질로 이용하였다(10).

\section{산성다당체 함량}

산성다당체 함량은 Do 등(11)의 방법에 따라 추출물 0.5 $\mathrm{mL}$ 에 carbazole $0.25 \mathrm{~mL}$ 를 첨가하고 $\mathrm{c}-\mathrm{H}_{2} \mathrm{SO}_{4} 3 \mathrm{~mL}$ 를 첨가 한 후 수옥조에서 $85^{\circ} \mathrm{C}, 5$ 분간 가열하고 실온으로 냉각시킨 후 $525 \mathrm{~nm}$ 에서 흡광도를 측정하였다. 함량산출을 위한 표 준물질은 galacturonic acid를 이용하였다.

\section{조사포닌 함량}

조사포닌의 분리 및 정량은 Ando 등(12)의 방법에 따라 인삼분말 $5 \mathrm{~g}$ 에 $80 \%$ methanol $100 \mathrm{~mL}$ 를 첨가한 후 잘 혼합 하여 수조 $80^{\circ} \mathrm{C}$ 에 2시간씩 4회 반복하여 추출하였다. 추출 한 용액을 여과지(Whatman No.2)로 여과한 다음 8,000 $\mathrm{rpm}$ 에서 20 분동안 원심분리 하였다. 얻어진 상층액을 $55-60^{\circ} \mathrm{C}$ 에서 $60 \mathrm{~mL}$ 로 감압농축한 후 분액여두로 diethyl ether 가용 성 성분을 제거하였다. 그리고 수포화부탄올 $50 \mathrm{~mL}$ 를 가해 추출하는 조작을 3 회 반복하여 n-butanol층으로 이행된 사 포닌을 분리 농축시켜 $60^{\circ} \mathrm{C}$ 에서 건조한 후 무게를 측정하였 다.

\section{진세노사이드 분석}

인삼사포닌인 진세노사이드 분석에 사용한 표준 물질은 $\mathrm{Rg} 1, \mathrm{Re}, \mathrm{Rf} . \mathrm{Rb} 1 . \mathrm{Rg} 2, \mathrm{Rc}, \mathrm{Rb}$, Rd의 8종을 Cerilliant (Round Rock, TX, USA)로부터 구입하였다. 진세노사이드 정량은 시료 분말 $1 \mathrm{~g}$ 에 $100 \mathrm{~mL}$ 가수하여 $95^{\circ} \mathrm{C}$ 에서 1 시간 추출하고 냉각하여 여과한 것을 열수추출물로 하였다. 여 기에 디에틸에테르 $100 \mathrm{~mL}$ 를 첨가하여 잘 혼합하고 에테르 가용성 분획을 제거한다. 물 분획물에 n-butanol을 $80 \mathrm{~mL}$ 넣고 추출하는 조작을 3 회 반복하여 부탄올 분획물을 얻어 진공농축기로 $55-60^{\circ} \mathrm{C}$ 에서 건조시킨다. 건조물에 메탄올 $5 \mathrm{~mL}$ 를 넣고 vortex 믹서로 혼합하여 조사포닌 용액으로 하였다. 이 용액을 멤브레인 필터 $(0.45 \mu \mathrm{m})$ 로 여과하여 시 험용액으로 하였다. 시료 $20 \mu \mathrm{L}$ 를 취하여 고속액체크로마 토그래피(Agilent 1260, Santa Clara, CA, USA)로 분석하였 으며 분리조건에서 이동상은 용매 $\mathrm{A}$ 의 증류수와 용매 $\mathrm{B}$ 의 acetonitrile을 농도구배 즉 용매 $\mathrm{A}$ 를 기준으로 $80 \%$ (5분), $60 \%$ (35분), $60 \%$ (45분), $80 \%$ (50분)로 하였다. 칼럼은 HiPep-
Candenza $\mathrm{C}_{18}-4615(150 \times 4.6 \mathrm{~mm})$, 칼럼온도는 $30^{\circ} \mathrm{C}$, 유속은 $1.0 \mathrm{~mL}$ 분, 검출기는 $\mathrm{DAD}$ detector로 파장 $203 \mathrm{~mm}$ 에서 측정 하였다(13).

색 도

색도는 Hunter $\mathrm{L}, \mathrm{a}, \mathrm{b}$ 및 $\Delta \mathrm{E}$ 값을 측정하였다. 백색도인 $\mathrm{L}$ (백색도/흑색도), 적색도인 $\mathrm{a}$ (적색도/녹색도), 황색도인 b (황색도/청색도), 색차인 $\Delta \mathrm{E}$ (백색판 기준) 값을 색차계 (Minolta spectrophotometer CM-3500d, Tokyo, Japan)로 측 정하였다.

\section{전자혀 측정}

추출물의 맛을 평가하기 위해 전자혀(Astree e-tongue, Alpha MOS., Toulouse, France)를 사용하여 Suh 등(14)의 방법에 준하여 분석하였다. 전자혀 기기는 자동식 샘플러 와 화학적으로 변형된 전위차 적정 센서가 장착되어 있어 신맛(SRS; sourness), 금속성맛(GPS; metallic), 짠맛(STS; saltiness), 감칠맛(UMS; umami), 양념맛(SPS; spiciness), 단 맛(SWS; sweetness) 및 쓴맛(BRS; bitterness)을 분석할 수 있다. 분석 조건은 시료 용량 $25 \mathrm{~mL}$, 시료 온도 $25^{\circ} \mathrm{C}$, 센서의 신호수신 120초로 하였으며, 5 회 반복 측정하였다.

\section{통계처리}

모든 실험은 2회 반복으로 실시하여 얻은 결과를 SPSS(Statistical Package for Social Science, SPSS Inc., Chicago, IL, USA) 통계프로그램-Version 19.0을 이용하여 분산분석(ANOVA) 후 평균표푼편차를 구하였다. 유의성 검증은 $\mathrm{p}<0.05$ 수준에서 시료간 Duncan's multiple range test를 실시하였다.

\section{결과 및 고찰}

\section{총 폴리페놀, 총 플라보노이드 함량}

Table 2는 열처리 방법을 달리하여 제조한 가공인삼으로 부터 총 폴리페놀, 총 플라보노이드, 총당, 산성다당체 및 조사포닌 함량을 나타낸 것이다. 홍삼 추출물의 총 폴리페 놀 함량은 열처리 방법에 따라 $\mathrm{ARG}, \mathrm{SRG}, \mathrm{RCRG}$ 경우 $9.60 \mathrm{mg} \mathrm{GAE} / \mathrm{g}, 5.79 \mathrm{mg} \mathrm{GAE} / \mathrm{g}, 5.21 \mathrm{mg} / \mathrm{g}$ 으로 autoclave에 의한 홍삼 열수추출이 유의적으로 가장 높은 값을 나타내었 다. Ning 등의 연구에 의하면 홍삼에 함유되어 있는 페놀성 성분은 maltol, esculetin, $p$-coumaric acid, cinnamic acid, quercetin이었으며, 구연산 처리시 홍삼에서 특이적으로 esculetin과 quercetin 함량이 증가하는 것으로 보고하였으 며 일반적으로 건조시간은 열풍건조시 약 11 일, 원적외선 으로 9일 소요되어 시간이 오래 걸리고, 이들 시료 추출물의 총 폴리페놀 함량은 $2.458 \mathrm{mg} / \mathrm{g}$ 을 나타내었다(15). 5년근 
수삼으로 가정용 전자레인지를 이용하여 제조한 홍삼(16) 으로부터 $80 \%$ 메탄올 추출물의 총 폴리페놀 함량은 0.431-0.456\%로 일반 홍삼과 유사하였으나 가정용 홍삼제 조기로 제조한 홍삼의 총 폴리페놀 함량은 약 2 배인 $0.938 \%$ 를 나타내었다. 가정용 홍삼제조기를 이용하여 홍삼을 제 조하는 경우 약 25 시간 쪄내야 하며, 제조한 홍삼은 검은색 으로 큰 차이를 보인다고 하였다. 추출음료용 최적의 분말 용 건조 홍삼의 제조를 위해 증삼조건, 건조조건은 중요하 며, 본 연구 조건에서는 증삼 중 autoclave에 의해 고온 고압 하에 인삼의 본체가 갈라져 용출량이 결정되고 이어지는 건조시간을 줄일 수 있었다. 총 플라보노이드 함량은 ARG, $\mathrm{WG}$ 의 경우 $3.38 \mathrm{mg} \mathrm{NE} / \mathrm{g}, 2.17 \mathrm{mg} \mathrm{NE} / \mathrm{g}$ 으로 홍삼이 백삼에 비해 함량이 높은 것으로 나타났다. 이들 페놀성 화합물과 항산화 활성의 상관관계 분석에 의하면(17) 항산화 활성은 페놀성 화합물의 함량에 약간 비례하는 것으로 보고하여 본 결과의 홍삼 제조 조건에 따른 함량차이와 관련한 항산 화 성분 조성에 대한 연구가 이루어져야 한다.
인삼박으로부터 산성다당체와 수용성다당체의 추출 함량 (20)은 홍삼박이 백삼박보다 높다고 하였다. 조사포닌 함량 은 ARG, RCRG, SRG 각각 $10.22 \mathrm{~g} / 100 \mathrm{~g}, 8.79 \mathrm{~g} / 100 \mathrm{~g}$, $8.31 \mathrm{~g} / 100 \mathrm{~g}$ 으로 $\mathrm{ARG}$ 가 유의적으로 높은 것으로 나타났 다. Lee 등은 조사포닌 함량은 국내산 홍삼의 경우 3.05-3.76\% 였으며 ginsenosides 중에서 $\mathrm{Rb} 1, \mathrm{Rb} 2, \mathrm{Rc}, \mathrm{Rd}$, $\mathrm{Re}, \mathrm{Rg} 1$ 함량은 $1.43 \%$, 특히 $\mathrm{Rb} 1, \mathrm{Re}, \mathrm{Rg} 1$ 성분이 많이 함유하고 있다고 하였다(21).

\section{진세노사이드}

열처리 방법을 달리한 인삼 열수추출물의 진세노사이드 함량을 측정한 결과는 Table 3 과 같다. 미확인 진세노사이 드를 제외한 주요 진세노사이드 농도는 $\mathrm{SWG}>\mathrm{RCRG}>$ $\mathrm{SRG}>\mathrm{WG}>\mathrm{NSWG}>\mathrm{ARG}$ 성분 순으로 함량이 높았다. 진세노사이드 $\mathrm{Rb} 1$ 의 농도는 $\mathrm{ARG}$ 와 $\mathrm{WG}$ 열수추출물에서 $1.52 \mathrm{mg} / \mathrm{g}, 0.33 \mathrm{mg} / \mathrm{g}$ 으로 각각 나타났다. 스팀 증숙한 ARG 의 열수추출물 중 시료 공통의 주요 진세노사이드의 총량은

Table 2. Functional components of hot water extracts from 6-year old ginseng with different treatments

\begin{tabular}{cccccc}
\hline Characteristics & $\begin{array}{c}\text { Total polyphenol } \\
(\mathrm{mgGAE} / \mathrm{g})\end{array}$ & $\begin{array}{c}\text { Total flavonoid } \\
(\mathrm{mgNE} / \mathrm{g})\end{array}$ & $\begin{array}{c}\text { Total sugar } \\
(\mathrm{g} / 100 \mathrm{~g})\end{array}$ & $\begin{array}{c}\text { Acidic polysaccharide } \\
(\mathrm{g} / 100 \mathrm{~g})\end{array}$ & $\begin{array}{c}\text { Crude saponin } \\
(\mathrm{g} / 100 \mathrm{~g})\end{array}$ \\
\hline $\mathrm{WG}^{\mathrm{l})}$ & $4.80 \pm 0.17^{2)(\mathrm{cs})}$ & $2.17 \pm 0.06^{\mathrm{b}}$ & $36.34 \pm 1.28^{\mathrm{a}}$ & $19.73 \pm 0.91^{\mathrm{a}}$ & $7.94 \pm 0.12^{\mathrm{c}}$ \\
SWG & $3.19 \pm 0.08^{\mathrm{d}}$ & $1.09 \pm 0.06^{\mathrm{d}}$ & $28.25 \pm 1.17^{\mathrm{b}}$ & $16.43 \pm 0.45^{\mathrm{b}}$ & $10.79 \pm 0.41^{\mathrm{a}}$ \\
NSWG & $5.10 \pm 0.15^{\mathrm{c}}$ & $1.72 \pm 0.06^{\mathrm{c}}$ & $34.17 \pm 0.79^{\mathrm{a}}$ & $10.57 \pm 0.38^{\mathrm{c}}$ & $6.94 \pm 0.16^{\mathrm{d}}$ \\
SRG & $5.79 \pm 0.11^{\mathrm{b}}$ & $1.92 \pm 0.08^{\mathrm{bc}}$ & $33.73 \pm 1.04^{\mathrm{a}}$ & $21.52 \pm 1.05^{\mathrm{a}}$ & $8.31 \pm 0.09^{\mathrm{bc}}$ \\
RCRG & $5.21 \pm 0.15^{\mathrm{c}}$ & $1.11 \pm 0.04^{\mathrm{d}}$ & $33.59 \pm 0.93^{\mathrm{a}}$ & $11.59 \pm 0.47^{\mathrm{c}}$ & $8.79 \pm 0.18^{\mathrm{b}}$ \\
ARG & $9.60 \pm 0.41^{\mathrm{a}}$ & $3.38 \pm 0.22^{\mathrm{a}}$ & $35.22 \pm 0.84^{\mathrm{a}}$ & $10.90 \pm 0.24^{\mathrm{c}}$ & $10.22 \pm 0.16^{\mathrm{a}}$ \\
\hline
\end{tabular}

${ }^{1)}$ WG, white ginseng; SWG, skin parts of white ginseng; NSWG white ginseng without skin; SRG, red ginseng by steaming with a steamer; RCRG, red ginseng by steaming with a rice cooker; ARG, red ginseng by steaming with a autoclave.

${ }^{2)}$ Values are mean $\pm \mathrm{SD}(\mathrm{n}=3)$.

${ }^{3)}$ Values with different superscript within the same column are significantly different $(p<0.05)$

\section{총당, 산성다당체 및 조사포닌 함량}

Table 2의 홍삼 추출물 3종의 총당 함량은 $\mathrm{ARG}, \mathrm{SRG}$, $\mathrm{RCRG}$ 각각 $35.22 \mathrm{~g} / 100 \mathrm{~g}, 33.73 \mathrm{~g} / 100 \mathrm{~g}, 33.59 \mathrm{~g} / 100 \mathrm{~g}$ 으로 유사한 것으로 나타났다. 그러나 수삼의 외피와 세근을 합 한 SWG의 총당 함량은 $28.25 \mathrm{~g} / 100 \mathrm{~g}$ 으로 유의적으로 낮은 값을 나타내었다. 산성다당체 함량은 $\mathrm{SRG}, \mathrm{RCRG}, \mathrm{ARG}$ 각각 $21.52 \mathrm{~g} / 100 \mathrm{~g}, 11.59 \mathrm{~g} / 100 \mathrm{~g}, 10.9 \mathrm{~g} / 100 \mathrm{~g}$ 으로 SRG가 유의적으로 높은 것으로 나타났다. 백삼 추출물인 WG의 함량은 $19.73 \mathrm{~g} / 100 \mathrm{~g}$ 로 연구 보고된 기호성 개선 인삼농축 액 제조 결과(18)인 추출조건에 따른 백삼의 4차 추출 시 함량 $(186 \mathrm{mg} / \mathrm{g})$ 과 유사하며, 추출 방법을 달리하여 쓴맛을 저감시키고 인삼향미의 강도를 저감시킨 제품을 개발하고 자 하였다. 연구에 의하면 수삼, 백삼, 홍삼 중의 다당체 함량은 홍삼이 수삼보다 월등히 많았고, 수삼은 백삼보다 많은 것으로 보고하였으며, 부위별 다당체 함량(19)은 홍삼 의 경우는 뇌두 > 주근 > 지근 > 미삼 > 표피의 순이었다.
$10.69 \mathrm{mg} / \mathrm{g}$ 으로 타 처리구에 비해 감소하였는데 이는 일반 적으로 홍삼 추출물의 농축액에서 볼 수 있는 $\operatorname{Rg} 3$ 등 진세 노사이드로의 전환에 의한 것으로 생각된다. Wang 등은 스팀처리하지 않은 인삼의 ginsenosides 조성은 $\mathrm{Rb} 1, \mathrm{Rb} 2$, $\mathrm{Rb} 3, \mathrm{Rc}, \mathrm{Rd}$ 이며, 스팀 처리 후 $\mathrm{Rg} 3, \mathrm{Rg} 5, \mathrm{Rk} 1$ 나아가 $\mathrm{Rh} 2$, $\mathrm{Rh} 3, \mathrm{Rk} 2$ 유도체를 얻을 수 있다고 하였으며 항암력은 Rh2, $\mathrm{Rh} 3, \mathrm{Rk} 2$ 등 진세노사이드 함량이 높은 홍삼에서 강하다고 하였다(22). 진세노사이드 변환과 관련하여 향후 수삼으로 부터 홍삼의 제조 과정에서 얻어진 증삼액인 용출액(Fig. $1 \mathrm{~A})$ 과 이를 사용하여 제조한 $\mathrm{ARG}$ 열수추출물(Fig. 1B)의 유도된 미확인 진세노사이드의 동정 및 기능성 소재화를 위한 후속 연구가 필요할 것으로 생각된다.

색 도

Table 4는 달리 제조한 인삼으로부터 열수추출한 추출물 의 색을 백색도, 적색도, 황색도 및 색차를 측정한 값이다. 
A

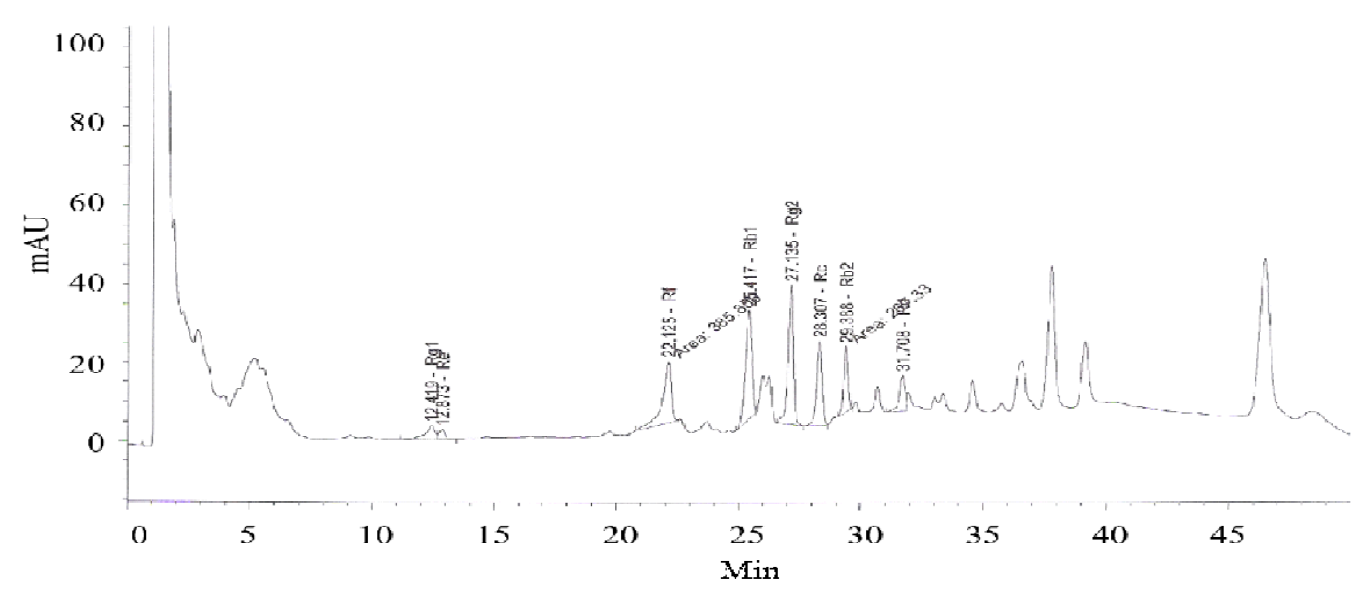

B

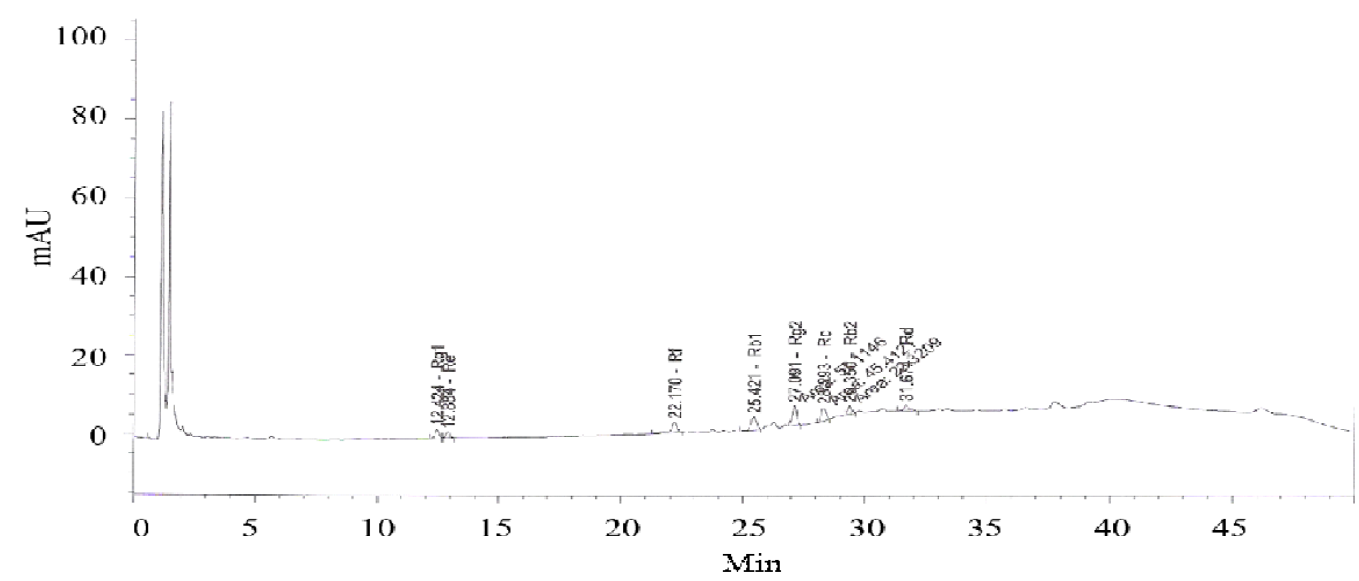

Fig. 1. HPLC chromatogram of collected steaming liquid (A) and hot water extract (B) of ARG from 6-year old ginseng with a autoclave. Chromatographic separation was accomplished using a gradient solvent system with acetonitrile-water; HPLC, high-performnce liquid chromatography; ARG, steaming liquid treated dried red ginseng by steaming with a autoclave; Rg1, ginsenoside Rg1; Rf, ginsenoside Rf; Rb1, ginsenoside Rb1; Rg2, ginsenoside Rg2; Rc, ginsenoside Rc; Rb2, ginsenoside $\mathrm{Rb} 2$; Rd, ginsenoside $\mathrm{Rd}$.

Table 3. Ginsenosides contents of hot water extracts from 6-year old ginseng with different treatments

\begin{tabular}{|c|c|c|c|c|c|c|c|c|c|}
\hline \multirow{2}{*}{ Characteristics } & \multicolumn{9}{|c|}{ Ginsenosides (mg/g) } \\
\hline & $\operatorname{Rg} 1$ & $\mathrm{Re}$ & $\mathrm{Rf}$ & $\mathrm{Rbl}$ & $\operatorname{Rg} 2$ & $\mathrm{Rc}$ & $\mathrm{Rb} 2$ & $\mathrm{Rd}$ & Total \\
\hline $\mathrm{WG}^{1)}$ & 2.59 & 5.71 & 1.11 & 0.33 & 4.22 & 2.78 & 1.47 & 0.75 & 18.96 \\
\hline SWG & 3.60 & 13.03 & 2.09 & 1.16 & 8.80 & 6.94 & 3.35 & 1.07 & 40.04 \\
\hline NSWG & 3.06 & 3.57 & 1.40 & 0.00 & 3.55 & 0.62 & 0.78 & 0.28 & 13.26 \\
\hline SRG & 2.13 & 4.95 & 1.20 & 0.56 & 6.08 & 3.14 & 2.84 & 0.61 & 21.51 \\
\hline RCRG & 3.38 & 6.35 & 1.67 & 0.50 & 7.81 & 3.78 & 2.35 & 0.66 & 26.50 \\
\hline ARG & 0.79 & 0.86 & 1.35 & 1.52 & 2.59 & 1.92 & 0.83 & 0.83 & 10.69 \\
\hline
\end{tabular}

${ }^{10}$ WG, white ginseng; SWG, skin parts of white ginseng; NSWG white ginseng without skin; SRG, red ginseng by steaming with a steamer; RCRG, red ginseng by steaming with a rice cooker; ARG, red ginseng by steaming with a autoclave.

$\mathrm{ARG}$ 의 백색도는 73.89 로 가장 낮고, WG가 가장 높은 것으 로 나타났다. 적색도 값은 1.79 로 $\mathrm{SRG}, \mathrm{RCRG}$ 와도 유의적 으로 높은 값을 나타내었다. 황색도 값은 27.8로 SRG 15.79,
$\mathrm{RCRG}$ 15.44에 비해 유의적으로 높게 나타났다. 색차인 $\Delta \mathrm{E}$ 는 27.8로 $\mathrm{SRG}$ 15.79, RCRG 15.44 보다 유의적으로 높은 데 이는 흑삼이 가지는 $\mathrm{L}$ 값의 저하, $\mathrm{a}$ 값과 $\mathrm{b}$ 값의 상승에 
의한 전반적인 색차가 반영된 것으로 다른 홍삼 뿐만 아니 라 일반 홍삼에서 볼 수 있는 색보다 흑삼에 가까운 색을 나타내었다. $120^{\circ} \mathrm{C}$ 에서 스팀처리한 $\mathrm{ARG}$ 는 부산물로 용출 액을 얻을 수 있는데 여기에는 각종 인삼 성분이 함유되어 있어서 회수하여 이용할 수 있다. Zhou 등은 홍삼제조시 steaming liquid에는 갈변물질 뿐만 아니라 진세노사이드, 다당체, 올리고당, 단당류 등이 화학반응에 의해 생성된다 고 하였다(23). 홍삼제조시 스팀 시간은 1-12시간, 건조는 $60^{\circ} \mathrm{C}$ 에서 24 시간 가능하고(24), 4년근 수삼을 $100-160^{\circ} \mathrm{C}$ 범 위 즉 $100^{\circ} \mathrm{C}(6-72 \mathrm{~h}), 120^{\circ} \mathrm{C}(1-12 \mathrm{~h}), 140^{\circ} \mathrm{C}(15-135 \mathrm{~min}), 16$ $0^{\circ} \mathrm{C}(5-35 \mathrm{~min})$ 의 조건이 있다고 했다(25). 또한 스팀 과정으 로 arginine과 당분이 함량이 증가되어 수삼에는 검출되지 않는 arginine-fructose(AF), arginine-fructose-glucose (AFG) 의 수용성 성분이 홍삼에 다량 함유되어 있다고 하였다(26). Autoclave에 의한 홍삼제조시 장시간 스팀처리하면 마이야 르반응에 의한 비효소적 갈변이 진행되어 인삼 뿐만아니라 증삼액을 이용한 홍삼추출물(ARG)의 흑색도가 증가하는 것으로 나타났다. 따라서 스팀처리 조건을 달리하여 제조 한 홍삼의 경우 색을 포함하여 성분의 변화가 크게 일어나 는 것으로 생각된다.

Table 4. Color properties of hot water extracts from 6-year old ginseng with different treatments

\begin{tabular}{ccccc}
\hline Characteristics & $\begin{array}{c}\text { Lightness } \\
(\mathrm{L})\end{array}$ & $\begin{array}{c}\text { Redness } \\
(\mathrm{a})\end{array}$ & $\begin{array}{c}\text { Yellowness } \\
(\mathrm{b})\end{array}$ & $\begin{array}{c}\text { Color difference } \\
(\Delta \mathrm{E})\end{array}$ \\
\hline $\mathrm{WG}^{1)}$ & $82.88 \pm 2.70^{2 \mathrm{a} 3)}$ & $0.17 \pm 0.01^{\mathrm{d}}$ & $4.22 \pm 0.81^{\mathrm{d}}$ & $13.76 \pm 0.22^{\mathrm{d}}$ \\
SWG & $81.59 \pm 1.38^{\mathrm{a}}$ & $0.27 \pm 0.03^{\mathrm{c}}$ & $6.39 \pm 0.03^{\mathrm{b}}$ & $15.76 \pm 0.18^{\mathrm{c}}$ \\
NSWG & $79.43 \pm 1.42^{\mathrm{a}}$ & $0.71 \pm 0.04^{\mathrm{b}}$ & $5.82 \pm 0.01^{\mathrm{c}}$ & $17.56 \pm 0.17^{\mathrm{b}}$ \\
SRG & $81.28 \pm 1.39^{\mathrm{a}}$ & $0.10 \pm 0.01^{\mathrm{d}}$ & $5.75 \pm 0.06^{\mathrm{c}}$ & $15.79 \pm 0.33^{\mathrm{c}}$ \\
RCRG & $81.47 \pm 1.68^{\mathrm{a}}$ & $0.20 \pm 0.02^{\mathrm{c}}$ & $5.26 \pm 0.01^{\mathrm{c}}$ & $15.44 \pm 0.26^{\mathrm{c}}$ \\
ARG & $73.89 \pm 2.60^{\mathrm{b}}$ & $1.79 \pm 0.17^{\mathrm{a}}$ & $16.68 \pm 0.10^{\mathrm{a}}$ & $27.80 \pm 0.49^{\mathrm{a}}$ \\
\hline
\end{tabular}

${ }^{10}$ WG, white ginseng; SWG, skin parts of white ginseng, NSWG white ginseng without skin; SRG, red ginseng by steaming with a steamer, RCRG, red ginseng by steaming with a rice cooker; ARG, red ginseng by steaming with a autoclave.

${ }^{2)}$ Values are mean $\pm \mathrm{SD}(\mathrm{n}=3)$.

${ }^{3)}$ Values with different superscript within the same column are significantly different $(\mathrm{p}<0.05)$.

\section{전자혀}

Fig. 2는 열처리 방법을 달리한 가공인삼의 맛성분을 주 요 성분분석법(principle component analysis; PCA)으로 그 패턴을 나타낸 것이다. 수삼으로부터 홍삼을 제조하는 과 정에 성분의 상호작용에 의한 처리구의 차이는 홍삼인 $\mathrm{ARG}$ 와 RCRG 시료, SRG 시료, 백삼인 WG, SWG, NSWG 시료에 있어서 뚜렷하게 열수 추출물의 전자혀 특성 변화로 나타났다. 신맛(SRS), 짠맛(STS), 감칠맛(UMS), 단맛 (SWS), 쓴맛(BRS)을 종합한 맛에 대한 분석값은 스팀 온도 등 가공의 정도에 따라 크게 영향을 받는 것으로 나타나 향후 인삼의 용도에 따라서 auclaving과 같은 고온 고압의 적정 가공 기술의 적용이 요구된다. Fig. 3은 맛 스크리닝 결과를 레이다 모형으로 나타낸 것으로 홍삼 추출물중 $\mathrm{ARG}$ 는 감미도인 SWS에서 높은 값을 나타내었는데 이는 autoclaving 과정에서 당류의 가수분해와 갈변물질에 따른 것으로 생각되며 향후 후속연구가 필요할 것으로 생각 된다.

\section{인삼 성분간의 상관관계}

Table 5는 인삼 성분중 총 폴리페놀, 총 플라보노이드, 총당, 산성다당체, 조사포닌 등 성분간의 상관관계 그리고 가공으로 크게 영향을 받는 색차 간의 상관관계를 나타낸 것이다. 총 폴리페놀과 총 플라보노이드는 0.792 로 정의 상관관계를 보였으며 $(\mathrm{p}<0.05)$, 총 폴리페놀과 색차는 0.8 로 정의 상관관계를 나타내었다. 이는 고온 고압으로 스팀처 리하면 열에 약한 가용성페놀성화합물은 감소하나 세포벽 구성 성분 중 페놀성 화합물의 가수분해로 추출물 중 총 함량은 증가할 것으로 생각되며, 특히 배당체 형태의 페놀 성 화합물 함량이 높으면 걀변을 포함한 흑색도가 증가할 것으로 생각된다.

Table 5. Pearson correlation coefficients between various characteristics values of hot water extracts from 6-year old ginseng with different treatments

\begin{tabular}{ccccccc}
\hline & Total polyphenol & Total flavonoid & Total sugar & Acidic polysaccharides & Crude saponin & Color difference $(\Delta \mathrm{E})$ \\
\hline Total polyphenol & 1.000 & $0.792^{* 1)}$ & 0.322 & 0.135 & 0.024 & $0.800^{*}$ \\
Total flavonoid & & 1.000 & 0.390 & 0.013 & 0.010 & 0.637 \\
Total sugar & & & 1.000 & 0.002 & 0.343 & 0.048 \\
Acidic polysaccharides & & & & 1.000 & 0.003 & 0.300 \\
Crude saponin & & & & 1.000 & 0.168 \\
Color difference $(\Delta \mathrm{E})$ & & & & & & 1.000 \\
\hline
\end{tabular}

\footnotetext{
${ }^{1)^{*}}$ Values represents $\mathrm{p}<0.05$
} 


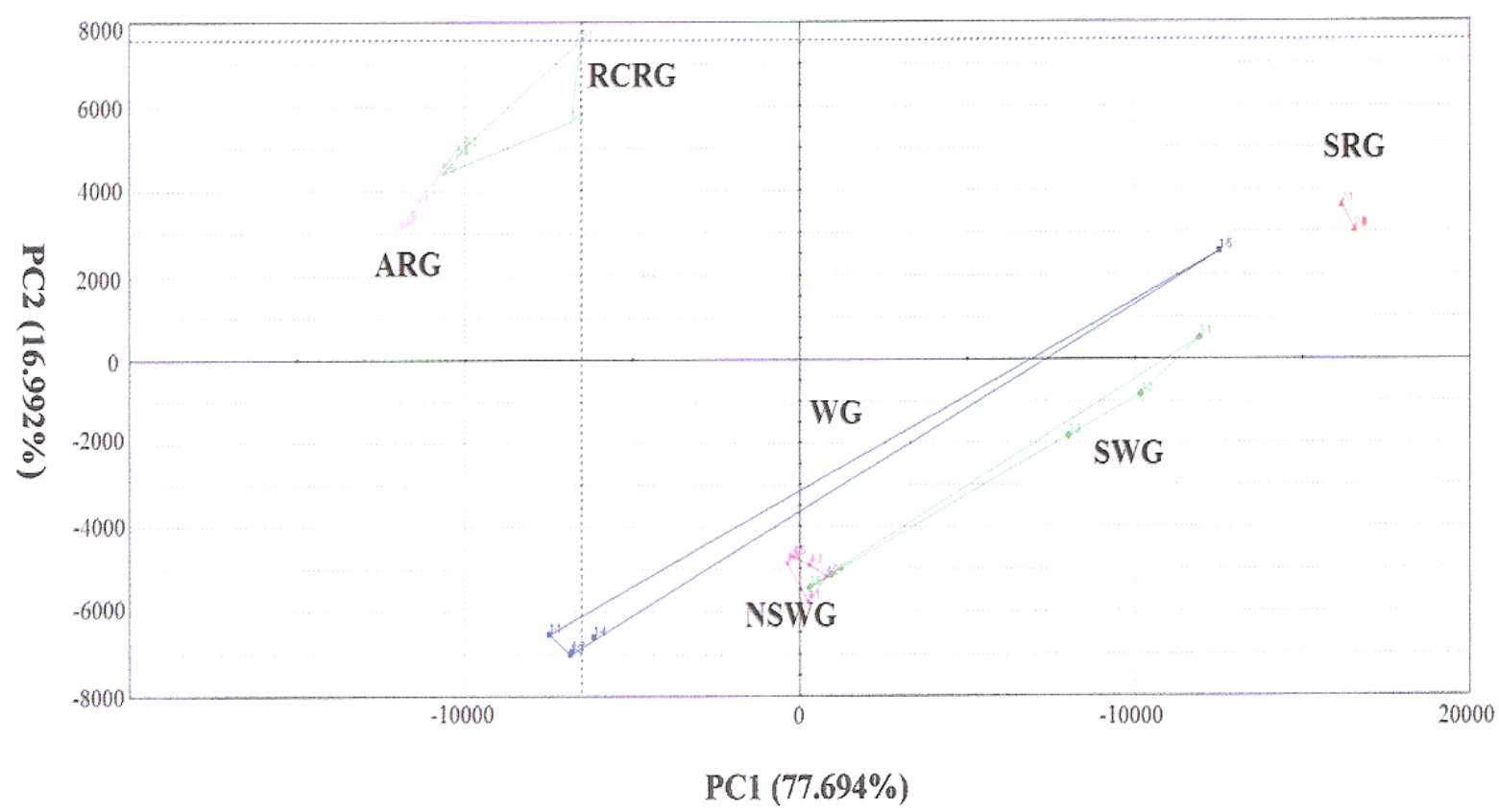

Fig. 2. Score plots of principal component analysis (PCA) for hot water extracts from 6-year old ginseng with different treatments by electronic tongue analysis.

WG, white ginseng; SWG, skin parts of white ginseng; NSWG white ginseng without skin; SRG, red ginseng by steaming with a steamer; RCRG, red ginseng by steaming with a rice cooker; ARG, red ginseng by steaming with a autoclave.

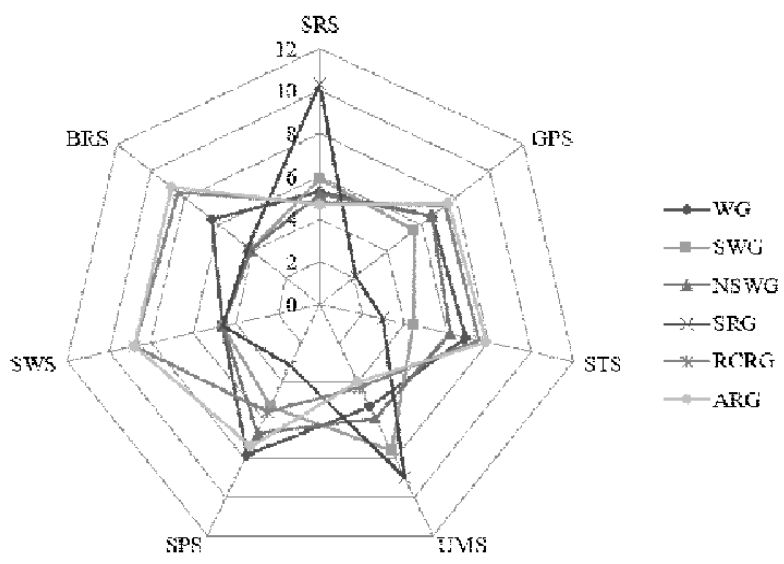

Fig. 3. Radar fingerprints of electronic tongue sensors for hot water extracts from 6 year old ginseng with different treatment.

WG, white ginseng; SWG, skin parts of white ginseng; NSWG white ginseng without skin; SRG, red ginseng by steaming with a steamer; RCRG, red ginseng by steaming with a rice cooker; ARG, red ginseng by steaming with a autoclave; SRS, sourness, GPS, metallic; STS, saltiness; UMS, umami; SPS, spiciness; SWS, sweetness; BRS, bitterness.

\section{요 약}

본 연구는 고온 고압의 autoclaving 조건에서 2시간 내외 로 증삼한 인삼과 그 용출액으로 2단계 열 풍건조법으로 제조한 홍삼을 분말로 하여 그 열수추출물에 대한 이화학적
특성을 조사하였다. 즉 시료로 사용한 홍삼의 제조는 고온 고압으로 증삼한 용출액을 건조시 증삼 표면에 바르고 건조 하여 외형이 흑삼 모양으로 변하였다. 홍삼 분말로부터 열 수추출물의 총 폴리페놀, 총 플라보노이드, 총당, 산성다당 체, 조사포닌 등의 함량을 분석하고, 색차계와 전자코를 이용하여 향미 성분을 측정하였다. Autoclave를 이용한 홍 삼 열수추출물(ARG)의 총 폴리페놀 함량은 $9.06 \mathrm{mg}$ $\mathrm{GAE} / \mathrm{g}$, 총 플라보노이드 $3.38 \mathrm{mg} \mathrm{NE} / \mathrm{g}$, 총당 $35.22 \mathrm{~g} / 100$ $\mathrm{g}$, 산성다당체 $10.90 \mathrm{~g} / 100 \mathrm{~g}$, 조사포닌 $10.22 \mathrm{~g} / 100 \mathrm{~g}$ 으로 나타났다. 본 홍삼제조법에 의해 얻어진 홍삼을 이용한 열 수추출물은 총 폴리페놀, 총 플라보노이드, 조사포닌 등의 최종 함량이 다른 홍삼 제조법에 비해 높게 나타났으며, 고온 고압으로 단시간에 얻은 증삼액인 용출액은 진세노사 이드 조성이 다양하였다. $\mathrm{Rb1}$ 을 포함한 인삼의 주요 진세노 사이드 총 함량은 $\mathrm{ARG}$ 에서 가장 낮은 $10.69 \mathrm{mg} / \mathrm{g}$ 으로 나타 났으며 가공 조건이 홍삼 특유의 진세노사이드로의 전환에 영향을 주었다. Autoclave로 얻어진 홍삼 및 용출액은 홍삼 성분의 저분자량으로의 변환을 통해 색의 강화 등 향미성분 이 개선되어 식품 뿐만 아니라 비식품의 소재 및 제품을 위한 수요가 기대된다.

\section{감사의 글}

본 연구는 중소벤처기업부와 한국산업기술진흥원의 “지 
역특화산업육성사업(R0005970)"으로 수행된 연구결과 입 니다.

\section{References}

1. Kim SJ, Shin JY, Ko SK (2016) Changes in the contents of prosapogenin in red ginseng (Panax ginseng) depending on the extracting conditions. J Ginseng Res, 40, 86-89

2. Lee KH, Lee DY, Lee SE, Nam KY, Hwang GB, Kim HD, Lee JW, Choi JH, Ahn YS, Kim SY, Kim GS (2016) Evaluation on extraction conditions and HPLC analysis method for ginsenosides in Panax ginseng. Korean J Med Crop Sci, 24, 47-54

3. Jeong HC, Hong HD, Kim YC, Rho J, Kim KT, Cho CW (2012) The research trend of ginseng processing technology and the status of ginseng industry. Food Science and Industry, 45, 59-67

4. Kim AJ, Lee SH, Jung EK (2013) Quality characteristics of Yanggaeng with white, red and black ginseng powder. J East Asian Soc Diet Life, 23, 78-84

5. Han ST, Whang WK, Kim IH, Yang BW, Cho SH, Ko SK (2005) Analysis of ginsenosides of black ginseng. Yakhak Hoeji, 49, 490-494

6. In JK, Lee BS, Kim EJ, Park MH, Yang DC (2006) Increase of functional saponin by acidic treatment and temperature of red ginseng extract. Korean J Plant Res, 19, 139-143

7. Lee GS, Nam KY, Choi JE (2013) Ginsenoside composition and quality characteristics of red ginseng extracts prepared with different extracting methods. Korean J Medicinal Crop Sci, 21, 276-281

8. Lee JW, Park CK, Do JH (2005) Antioxidant activity of water soluble browning reaction products from Korean red ginseng. J Ginseng Res, 29, 44-48

9. Kim IS, Jin SK, Kang SN (2011) Effect of red ginseng extracts on the qualities of low salt and low fat pork sausage. Korean J Food Sci Ani Resour, 31, 588-595

10. Dubois M, Gilles KA, Hamilton JK, Rebers PA, Smith F (1956) Colorimetric method for determination of sugars and related substances. Anal Chem 28, 350-352

11. Do JH, Lee HO, Lee SK, Jang JK, Lee SD, Sung HS (1993) Colorimetric determination of acidic polysaccharide from Panax ginseng, its extraction condition and stability. Korean J Ginseng Sci, 17, 139-144

12. MFDS (2016) Ginsenosides. Testing methods of health functional food, Ministry of Food and Drug Safety, Cheongju, Korea, p 367-371

13. Ando T, Tanaka O, Shibata S (1971) Chemical studies on the oriental plant drugs. XXV. Comparative studies on the saponins and sapogenins of ginseng and related crude drugs. Syoyakugaku Zasshi, 25, 28-32

14. Suh YS, Lee SH, Shang Y, Yoon JR, Lee WJ (2014) Changes in antioxidant activities and flavor patterns of Coffea arabica beans during roasting. Korean J Food Preserv, 21, 224-230

15. Ning X, Lee J, Han C (2015) Drying characteristics and quality of red ginseng using far-infrared rays. J Ginseng Res, 39, 371-375

16. Kim MH, Kim KT, Cho CW, Rho J (2012) Easy red ginseng production using household microwave ovens. Korean J Food Cookery, 28, 623-628

17. Lee JW, Mo EJ, Choi JE, Jo YH, Jang H, Jeong JY, Jin Q, Chung HN, Hwang BY, Lee MK (2016) Effect of Korean red ginseng extraction conditions on antioxidant activity, extraction yield, and ginsenoside $\operatorname{Rg} 1$ and phenolic content: optimization using response surface methodology. J Ginseng Res, 40, 229-236

18. Choi JW, Oh MJ, Ha SK, Park Y, Park HY (2016) Characterization and optimization for beverage manufacture using Korean red ginseng extract. Korean J Food preserv, 23, 319-325

19. Han YN, Kim SY, Lee HJ, Hwang WI, Han BH (1992) Analysis of Panax ginseng polysaccharide by Alcian blue dye. Korean J Ginseng Sci, 16, 105-110

20. Choi YJ, Hwang KH (2011) Analysis of the extraction condition of soluble acidic polysaccharides from ginseng marc. Kor J Pharmacogn, 42, 82-88

21. Lee JW, Lee SK, Do JH (2002) Comparison of the content of saponin and mineral component in Korean red ginseng and other red ginseng. J Ginseng Res, 26, 196-201

22. Wang CZ, Anderson S, Du W, He TC, Yuan CS (2016) Red ginseng and cancer treatment. Chin J Nat Med, 14, 7-16

23. Zhou SS, Xu J, Kong M, Yip KM, Xu JD, Shen H, Zhao ZZ, Li SL, Chen HB (2017) Synchronous characterization of carbohydrates and ginsenosides yields deeper insights into the processing chemistry of ginseng. J Pharm Biomed Anal, 145, 59-70

24. Zhou Y, Yang Z, Gao L, Liu W, Liu R, Zhao J, You J (2017) Changes in element accumulation, phenolic metabolism, and antioxidative enzyme activities in red-skin roots of Panax ginseng. J Ginseng Res, 41, 
307-315

25. Ryu J, Lee HW, Yoon J, Seo B, Kwon DE, Shin UM (2017) Effect of hydrothermal processing on ginseng extract. J Ginseng Res, 41, 572-577
26. In G, Ahn NG, Bae BS, Lee MW, Park HW, Jang KH, Cho BG, Han CK, Park CK, Kwak YS (2017) In situ analysis of chemical components induced by steaming between fresh ginseng, steamed ginseng, and red ginseng. J Ginseng Res, 41, 361-369 